\title{
Trans-generational transfer of early maladaptive schemas - a preliminary study performed on a non-clinical group
}

\author{
Dorota Macik ${ }^{1 \cdot A, C, D, E}$, Jan Chodkiewicz $z^{2 \cdot D, E, F}$, Daria Bielicka ${ }^{3 \cdot B}$ \\ 1: The John Paul II Catholic University of Lublin, Poland \\ 2: University of Lodz, Poland \\ 3: University of Finance and Management, Warsaw, Poland
}

BACKGROUND

The maladaptive schemas theory assumes the creation of schemas as a result of relationships with parents during childhood. The aim of the study was to answer questions about the relations between dysfunctional parents' schemas and their parental attitudes and their children's schemas.

\section{PARTICIPANTS AND PROCEDURE}

Eighty people participated in the study: 20 full families with grown children: a daughter and a son. The Questionnaire of Retrospective Assessment of Parental Attitudes (KPR-Roc) by Plopa and the Young Schema Questionnaire in its short form (YSQ-S3) were used.

\section{RESULTS}

The results indicate that in the case of daughters the relationships between parental attitudes and schemas relate primarily to the perception of the mother's attitudes. The strongest positive relationship between maladaptive daughter's schemas were in relation to an excessively demanding attitude of the mother. There were no relations between the perception of the father's attitudes and schemas of daughters. In the case of boys there were less significant correlations for both the perception of the mother and father. With regard to the relationship between parents' schemas and children's schemas, such mothers' schemas as defectiveness, vulnerability to harm or illness and absolute severity and such fathers' schemas as defectiveness, entanglement and self-sacrifice showed especially strong links with daughters' schemas. The strongest relationships with sons' schemas occurred in relation to the mother's schema connected with pessimism and the father's vulnerability to harm.

\section{CONCLUSIONS}

Young's schemas theory seems to be significant from the perspective of understanding intergenerational transfers of beliefs and accompanying behaviours.

\section{KEY WORDS}

parental attitudes; early maladaptive schemas; Young's schemas theory

Corresponding Author - Dorota Mącik, Ph.D., The John Paul II Catholic University of Lublin, 14 Racławickie Avenue, 00-950 Lublin, e-mail: dorota_macik@tlen.pl

AUthors' CONTRiBution - A: Study design - B: Data collection - C: Statistical analysis · D: Data interpretation .

E: Manuscript preparation · F: Literature search · G: Funds collection

TO CITE THIS ARTICLE - Mącik, D., Chodkiewicz, J., \& Bielicka, D. (2016). Trans-generational transfer of early maladaptive

schemas - a preliminary study performed on a non-clinical group. Current Issues in Personality Psychology, 4(3), 132-145.

RECEIVED 04.04.2016 · REVIEWED 09.05.2016 · ACCEPTED 31.05.2016 · PUBLISHED 11.07.2016 


\section{BACKGROUND}

Cognitive-behavioural therapy (CBT) is an extremely popular and widely empirically verified trend of psychotherapy (Thoma, Pilecki, \& McKay, 2015). Its main objective is discovering and changing the patient's dysfunctional beliefs, which leads to the elimination or at least a reduction of the degree of psychopathological symptoms and an improvement in the quality of life. A specific "supplement" of this therapy is one of its trends defined as "a new wave" of CBT - the theory of Young's early maladaptive schemas (EMS) (Young, 1999; Young, Klosko, \& Weishaar, 2014). According to the assumption of the theory based on the experiences in an emotional relationship with meaningful people in childhood and the way in which basic needs are satisfied, the foundations of the assumptions (schemas) concerning self-knowledge and knowledge about the world are created. If important needs are not satisfied, the schemas which are created can be of a dysfunctional character. On the basis of these basic, early schemas, in the course of development and the acquisition of self-awareness, core and conditional beliefs are created. These beliefs concern oneself and the world as well as the rules that govern life. The schemas have a tendency to self-confirmation; therefore, they are developed and strengthened throughout the whole life, despite their dysfunctionality (Beck, Freeman, Davis, \& Cierpisz, 2005; Young, Klosko, \& Weishaar, 2014).

Of course, parents as well as anyone else taking care of a child have basic schemas and beliefs. The content of these beliefs determines, among other things, the methods of their functioning in a relationship and creating the bonds which translate into the parental attitudes that they present to their children (cf. Grzegorzewska, 2012). In the normal course of events, the question can arise as to whether dysfunctional schemas are connected with parental attitudes and whether the schemas are in any way passed on from parents to children.

In the literature on the subject, it is emphasized that the parental attitudes presented towards children are connected, in a significant way, with the creation in children of generalized positive (in the case of safe attitudes) or negative (in the case of unsafe attitudes) models of self-assessment or assessment of the world (Bowlby, 2000, as cited in: Marchwicki, 2004). They are also responsible for creating specific characteristics (Ostafińska-Molik \& Wysocka, 2014), a kind of created bond (Marchwicki, 2004) and also a variety of mental disorders such as anxiety and somatoform disorders (Sobański et al., 2013). On the other hand, it is known that early maladaptive schemas are related directly to personality disorders and mental disorders (Beck, Freeman, \& Davis, 2005; Bosmans, Braet, \& Van Vlierberghe, 2010; Carr \& Francis, 2010; Cece- ro, Marmon, Beitel, Hutz, \& Jones, 2004; Mącik \& Sas, 2015; Mącik \& Shchehelska, 2015; Young, Rygh, Weinberger, \& Beck, 2008). Based on the above-mentioned empirically verified data, it can be assumed that there might be connections between parental attitudes and also early maladaptive schemas of parents and their children. However, in the literature there are no attempts to evaluate whether there are such connections and, if so, what kind they are. A few studies indicate the role of parental attitudes and the mediation role of schemas in problematic behaviour (Dale, Power, Kane, Stewart, \& Murray, 2010; Field, Francis, \& Carr, 2015; Hoffart Lunding \& Hoffart, 2014; Turner, Rose, \& Cooper, 2005). Also connections of an authoritarian style with some dysfunctional schemas have been proven (Esmali Kooraneh \& Amirsardari, 2015). The connection of the father's behaviour in a relationship with a child with schemas created by the child was also assessed (Monirpoor, Gholamyzarch, Tamaddonfard, Khoosfi, \& Ganjali, 2012). The research mentioned above leads to the conclusion that there is a connection between parents' schemas and children's schemas created on the basis of the quality of the relationships with parents, whose quality results from, among other things, parents' schemas. However, the literature does not provide us with an unambiguous solution to the problem.

Therefore, the following research questions were posed:

1. What are the connections between the parental attitudes of mothers and fathers and early maladaptive schemas of their children?

2. What are the connections of early maladaptive schemas of parents with the schemas of their children? Due to the wide range of analyses and the exploratory character of studies, directional research hypotheses were not set.

\section{PARTICIPANTS AND PROCEDURE}

In order to obtain initial answers to the above questions, 80 people were surveyed. There were 20 two-parent unreconstructed families with adult children: a daughter and a son. The parents were in the age range $47-63(M=53.83, S D=4.28)$, and the children were in the age range $22-35(M=27.83, S D=3.26)$. The exclusion criterion was the existence of any problems in the family connected with the mental health of any member. Such a group was adopted due to the possibility of a direct comparison of the analysed variables between the generations in a set of dependent groups that allowed for a conclusion in an intergenerational set.

To measure the variables, the following tools were used:

1. Parental attitudes: The questionnaire of the Retrospective Assessment of Parents' Attitudes (KPR- 
Roc), by Plopa (2008). The scale is used for the diagnosis of relationships with parents in a retrospective assessment done by the grown-up child in five dimensions: rejection-acceptance attitude, over-demanding attitude, autonomy attitude, inconsistent attitude, overprotective attitude. The tool consists of two versions: the assessment of a mother and the assessment of a father; each version has 50 statements. The task of the tested person is to refer to these statements using a 5-point scale where 1 stands for definitely she/he was not like that and 5 stands for definitely she/he was like that. The reliability of the tool measured with Cronbach's $\alpha$ coefficient in the normalization test was $.86-.93$ for the mothers' version and $.84-.90$ for the fathers' version.

2. Young's Early Maladaptive Schemas (EMS): Young Schema Questionnaire - the abbreviated version YSQ-S3, by Young, translated into Polish by Justyna Oettingen. The tool is used for the diagnosis of 18 early maladaptive schemas allocated to five areas (domains) dependent on the kind of unsatisfied basic needs (Young et al., 2014):

- Disconnection and Rejection; 5 schemas: abandonment/instability, mistrust/abuse, emotional deprivation, defectiveness/shame, social isolation.

- Insufficient Autonomy and Performance; 4 schemas: dependence/incompetence, vulnerability to harm or illness, enmeshment/undeveloped self, failure.

- Impaired Limits; 2 schemas: grandiosity, insufficient self-control.

- Other Directedness; 3 schemas: subjugation, self-sacrifice, approval-seeking).

- Overvigilance and inhibition; 4 schemas: negativity/pessimism, emotional inhibition, unrelenting standards/hypercriticalness, punitiveness).

The method consists of 90 statements for which the tested person uses the 6-point scale where 1 stands for completely untrue about me and 6 stands for perfectly describes me. In the present research, the analysis of reliability using Cronbach's $\alpha$ method for the whole scale was .92, and for individual schemas these values ranged from .86 to .97 . There are numerous language versions of the adaptive tool (e.g. Calvete, Orue, \& González-Diez, 2013; Kriston, Schäfer, Jacob, Härter, \& Hölzel, 2013; Lachenal-Chevallet, Mauchand, Cottraux, Bouvard, \& Martin, 2006; Saritaş \& Gençö, 2011). A Polish version is in progress.

The research was carried out in accordance with the standards for carrying out psychological research. Full anonymity of the tested people and their right to withdraw from the research at any stage were retained. The research was not sponsored or financed from external resources.

\section{RESULTS}

\section{EVALUATION OF PARENTAL ATTITUDES AND SCHEMAS}

In the first stage, daughters and sons were compared in terms of their perception of the parental attitudes of their mothers and fathers. The results obtained (not presented here due to lack of space) showed that children regardless of their gender perceived their parents' attitudes in the same way. It suggested that parents did not favour children in any way and used the same educational techniques for them. Possible differences between children were influenced by other things rather than their different treatment.

Another step was to determine the connections between the parental attitudes of fathers and mothers and the schemas of daughters and sons. The Pearson correlation coefficients obtained are presented in Tables 1 and 2 .

The results presented in the tables enable us to answer the first question posed related to the connections between the parental attitudes of mothers and fathers and the early maladaptive schemas of their children. They indicate significant differentiation of the mutual dependency of the perception of parents' attitudes and their own schemas between the groups of daughters and sons. As far as daughters are concerned, there are much stronger relationships and, most of all, they concern the perception of their mother's attitudes. Strong positive correlations with excessive requirements and inconsistency indicate strengthening schemas from the domains of disconnection and rejection and impaired autonomy. In turn, attitudes of acceptance and autonomy seem to be a factor which minimizes the intensification of schemas from these areas. Another essential fact is that perception of parental attitudes by a child is connected only with the schemas from these two domains, while in other domains (except the schema pessimism) basically these connections do not occur. What is interesting is that there are almost no connections between the perception of a father's attitudes and a daughter's schemas. It suggests the mother's definitely stronger influence on creating early schemas in daughters while the father's influence is decidedly slight.

As far as sons are concerned, we do not observe such a great number of connections as in a mother-daughter dyad. The occurring correlations are strong, indeed, but sporadic in the case of the perception of a father's and mother's attitudes. It may signify that the parents have a lesser influence on shaping the dysfunctional schemas in boys as compared to girls.

In the next step, the similarities between the early maladaptive schemas of parents and children were 


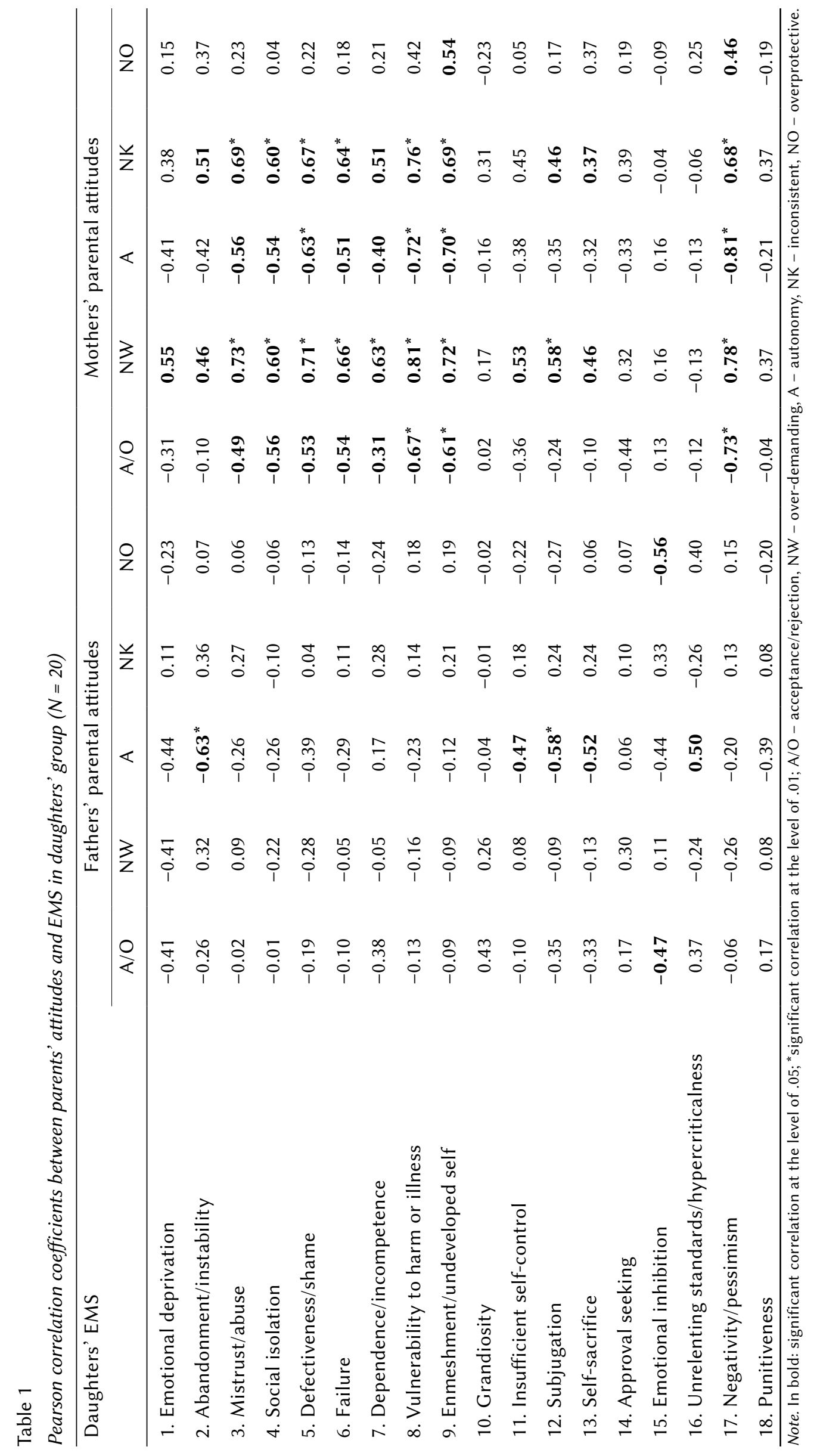




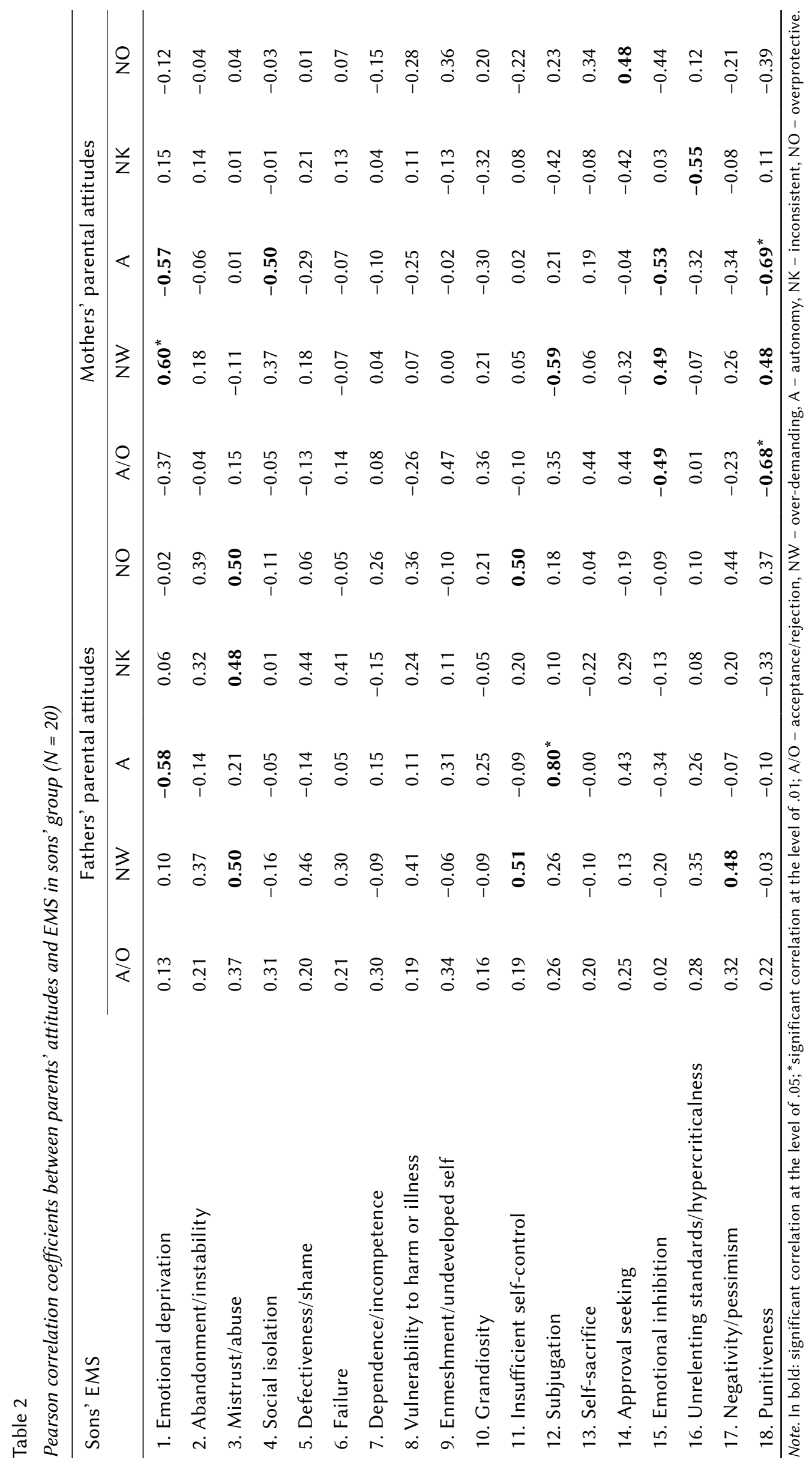


assessed. For this purpose, Pearson's correlation coefficients were calculated once again between schemas of mothers and their children and fathers and their children. The results obtained are presented in the Tables 3-6.

On the basis of the results it is possible to answer the question concerning the connections of early maladaptive schemas of parents with the schemas of their children. The data analysis brings attention, most of all, to the interchangeability of the schemas of daughters and their parents, both fathers and mothers. In the case of mothers, the most significant correlations can be observed in the domain Impaired autonomy and Performance - high intensification of these schemas in mothers is related to stronger schemas in daughters. In the case of fathers, there are definitely many more connections like these, the most in the domains Other directedness and Impaired autonomy. Sets of mutual dependencies of schemas of daughters and their parents are not the same, which indicates a different kind of mutual influence.

On the other hand, in the case of sons generally a lower number of correlations can be observed although slightly more in a mother/son dyad than a father/son dyad. The strongest connections in the case of a mother are observed for the schemas Pessimism and Abandonment, and in the case of fathers for Vulnerability to harm, Admiration-seeking and Emotional inhibition.

\section{DISCUSSION OF RESULTS}

The data presented above give us a lot of interesting conclusions which may become the starting point for more targeted research on the influence of a parent's schemas for strengthening or weakening the schemas created in a child.

The adopted research model study of a correlative character does not allow for conclusions to be drawn about the influence of one variable on another. However, referring to Young's theory, according to which the EMS is a relatively constant structure created in childhood under the influence of emotional experiences in relation to meaningful people (Young, 1999; Young et al., 2014), it can be assumed that, in the case of observed interdependences, it is rather the degree of intensification of the parents' schemas which will play an important role in the intensification of the schemas in children.

A detailed analysis of the indexes obtained for a mother/daughter dyad indicates that the schema Vulnerability to harm by a mother correlates the most with dysfunctional schemas in daughters. Great anxiety, concerns, and conviction about the inevitability of unpleasant events which cannot be prevented are related to the increase in intensification of almost all schemas in daughters when the strongest connection is the schema of Incompetence expressing itself in helplessness and dependence on others in everyday matters. The number of connections for this mother's schema indicates that being fearful, apprehensive, and thinking about the occurrence of negative events do not give the daughter a sense of security and that is why she is not able to create a self-image as an effective person coping with everything. Similarly, the mother's conviction about her inferiority and the necessity of hiding her real self from others for fear of being rejected (Defectiveness) is favourable to the intensification of the daughters' schemas especially in the domains Disconnection/rejection and Impaired autonomy. It means that the daughters of mothers with a domineering schema of "Defectiveness" become convinced that they cannot count on others to satisfy their own needs, especially their needs of acceptance and safety, and also their conviction in independent and effective functioning weakens. It is also worth noting the schema of Punitiveness of mothers showing strictness, tendency to punish, and difficulty in forgiving mistakes. Daughters of such mothers are characterised, most of all, by an intensified schema of Abandonment and Failure expressing their conviction that others are unpredictable, punishing, whereas I am weak, incompetent, helpless. Also connections of the schema Failure with the schemas of the daughters are noticeable.

In the case of the mother/son dyad, a completely different set of schemas significantly connected with one another are observed. What is more, the coefficients are mostly of an inversely proportional character. The more intensified is the schema Pessimism of mothers, the weaker are the developed schemas Emotional deprivation, Defectiveness, Failure, Entanglement and Self-sacrifice in sons. It can be understood as the specific objection of sons to the negative predictions of mothers that everything will be unfavourable; therefore, they try to maintain a positive self-image as effective people who can cope with everything, who are independent, and that is why they do not create developed schemas of Defectiveness or Failure. On the other hand, a worrying mother may give so much attention that the schema of Emotional deprivation is not developed. A similar mechanism seems to underlie the connections of a mother's defectiveness schema with Grandiosity and Punitiveness in sons: a mother convinced of her own inferiority evokes in sons the opposite conviction: of their own special rights, rivalry and proving their own superiority over other people and also punishing (and self-punishing) for mistakes, strictness, the necessity to achieve high expectations.

The schema Emotional deprivation of a mother (not showing any connections with daughters' schemas) in the case of sons is related negatively to Mistrust and positively to Enmeshment and Self-sacrifice. It can mean that the sons of mothers who are 


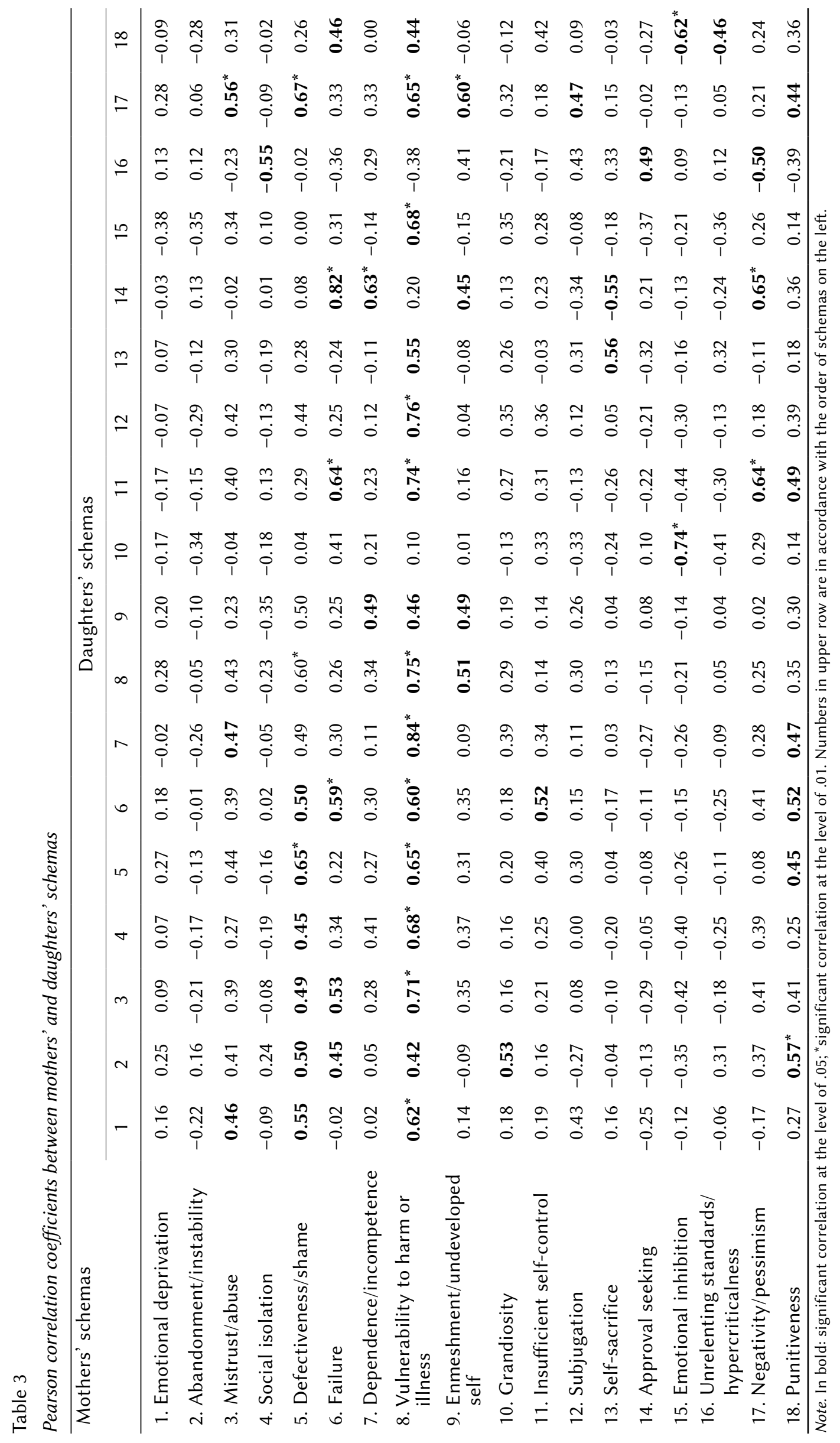




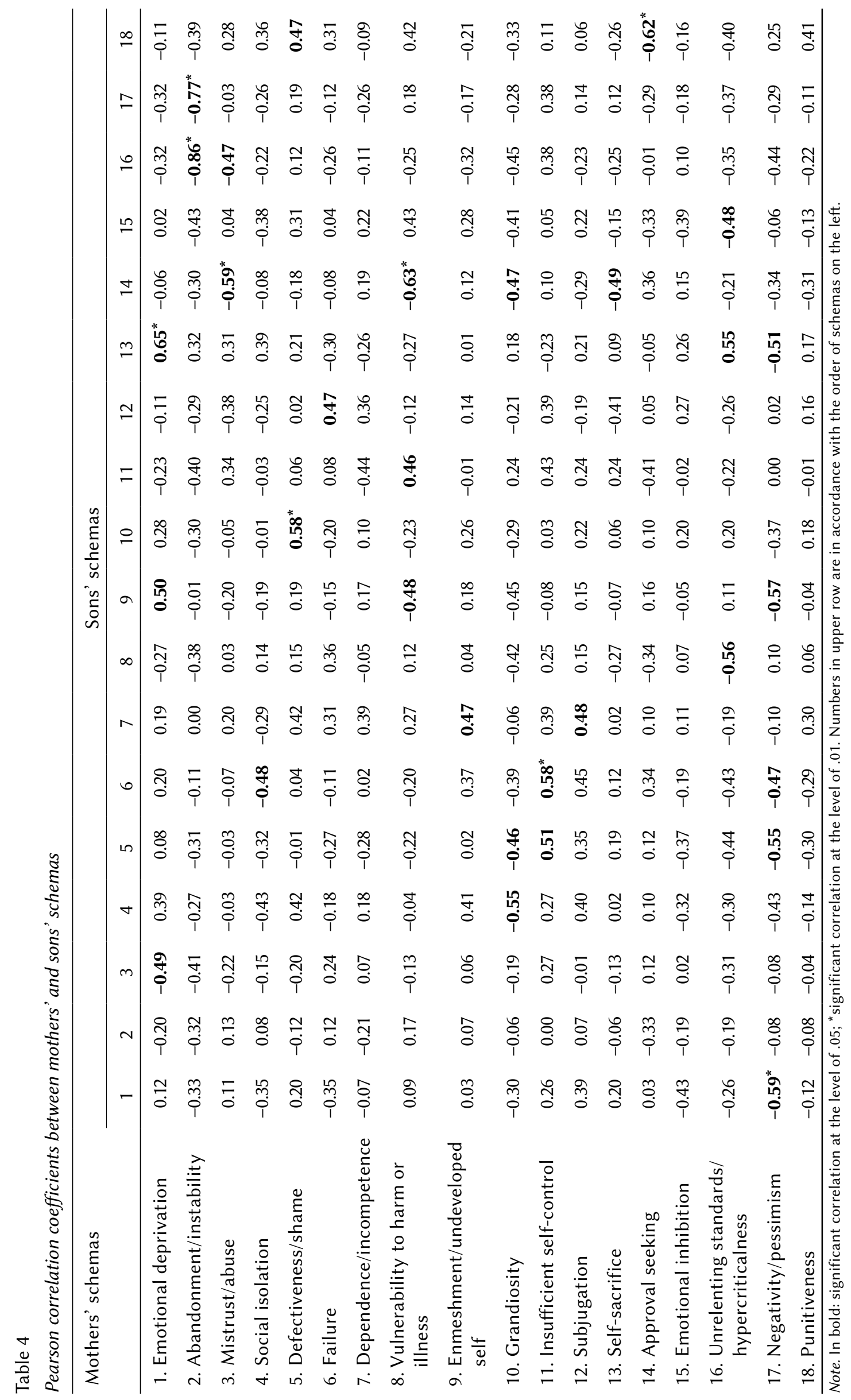




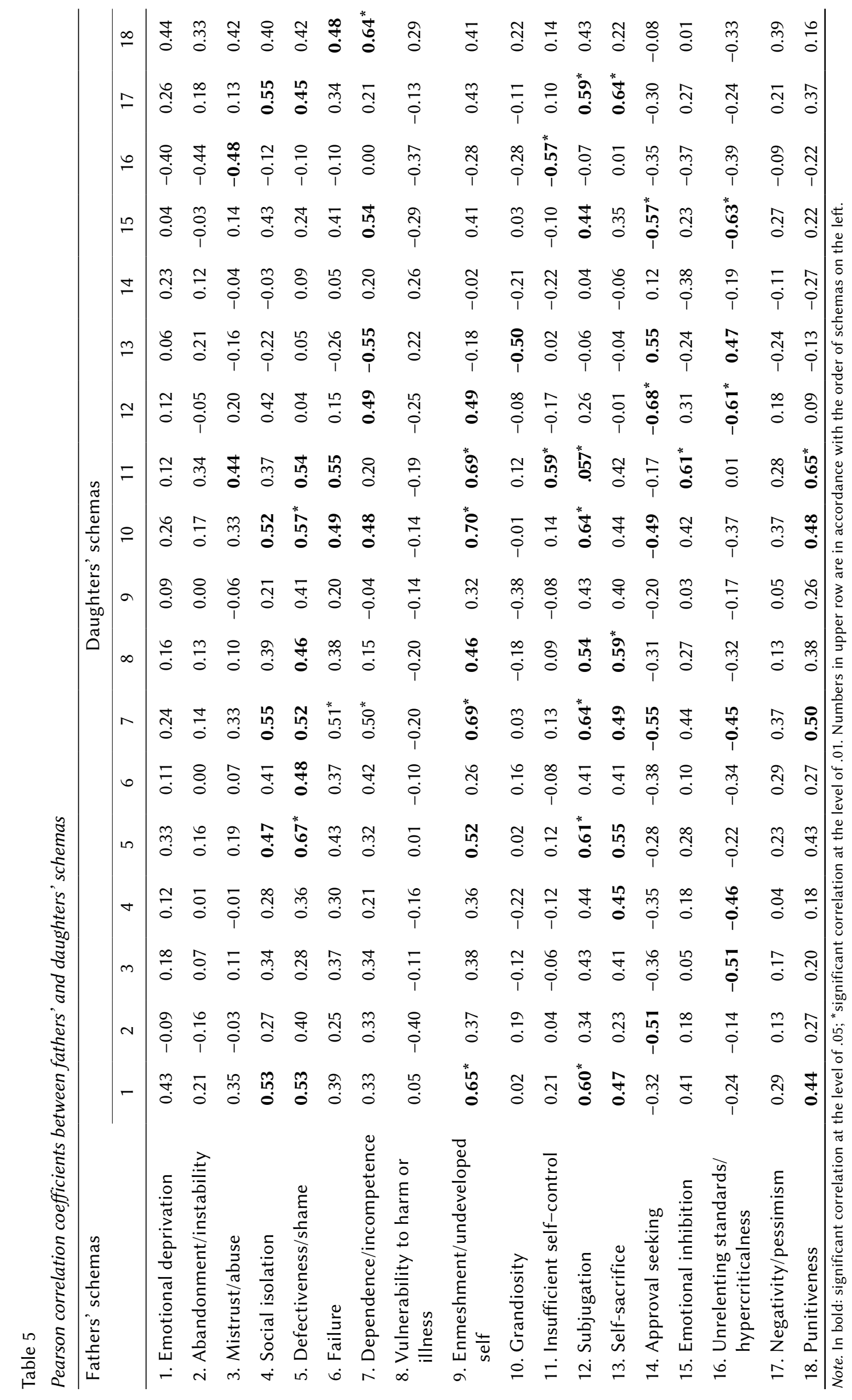




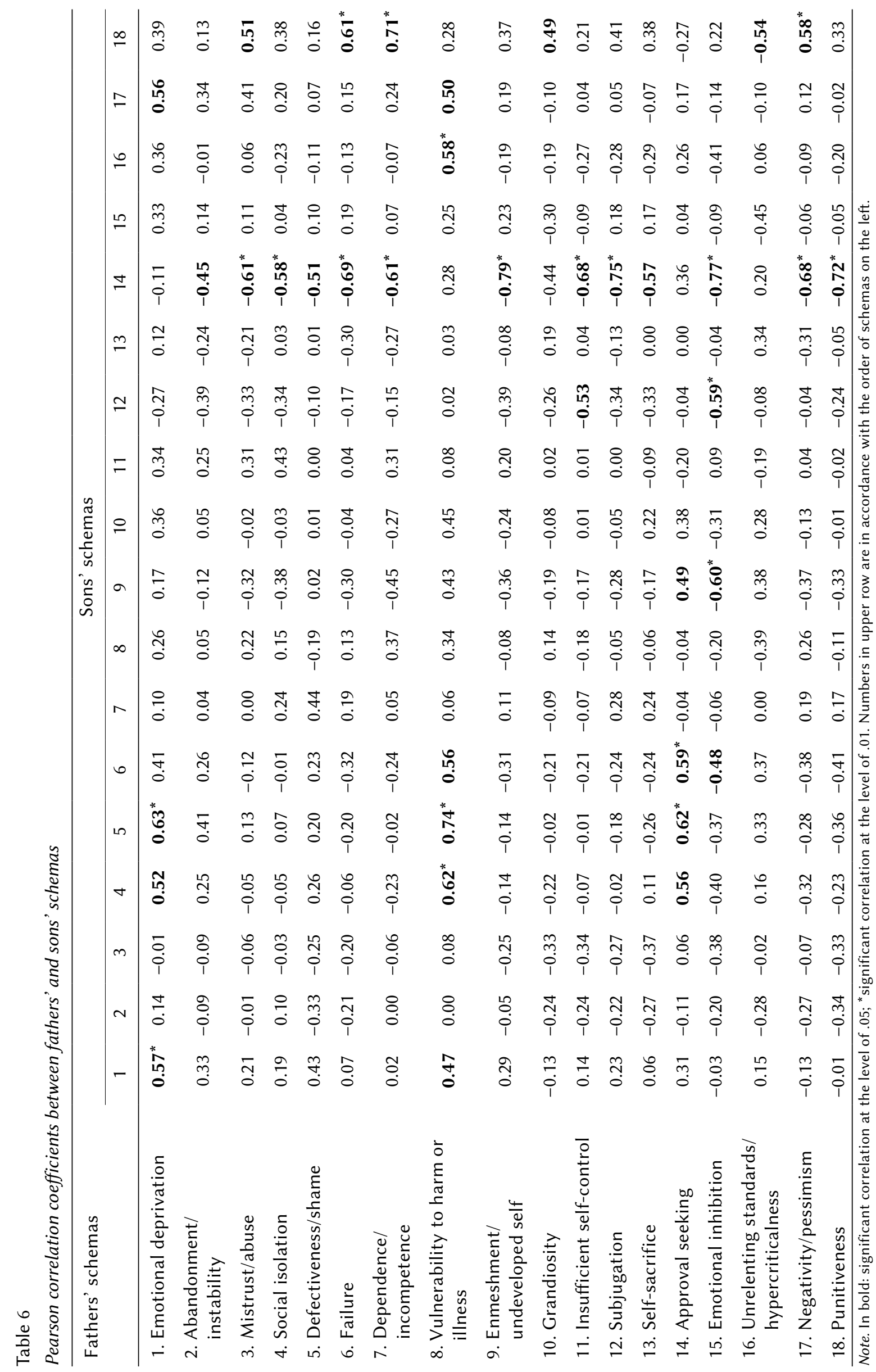


convinced that nobody can satisfy their emotional needs (understanding, attention, support, warmth) do not gain the convictions, indeed, that other people cause emotional harm; however, to a high degree they withdraw from the realization of their needs in favour of others (including his mother), and they are also characterized by a tendency to excessive emotional engagement with loved ones. This may suggest a desire for taking care of an emotionally weak mother at the cost of their own development.

Summing up the relationships between the schemas of mothers and their children, most of all, it should be emphasised that daughters seem to respond to their mothers' schemas in a complementary way so as to satisfy their mothers' needs and behave according to their convictions entering their vision of the world. In this way, to a certain degree, they confirm their mothers' convictions providing additional evidence for their validity; however, mothers also confirm their daughters' convictions. Hence, the correlations obtained are strong and positive. It is different in the case of children. Their schemas are indeed complementary to those of their mothers; however, most of the significant connections are of a negative character, which indicates a desire for the determination of one's own identity or identity typical of their own sex. At the same time, it should be remembered that some mothers' schemas are important for daughters, others for sons.

The second analysed group of relationships consists of the connections between the fathers' schemas and their children's.

In a father/daughter dyad a great number of observed connections are paid attention to. They are mostly of a positive character.

Three fathers' schemas - Defectiveness, Enmeshment and Subjugation - are related significantly to their daughters' schemas. These schemas are expressed in the convictions concerning their own worthlessness, disadvantages, inferiority; the unimportance of their own needs for others and in consequence being subordinate to others; striving for excessively close emotional relationships which ensure support and enable survival. Due to such fathers' convictions their daughters' convictions are such that their emotional needs will not be satisfied; they also strengthen their conviction of their own inferiority, inadequacy in features of "self" as well as competences and achievements. At the same time, the father with such convictions is a weak father and can strengthen in his daughter the convictions of superiority, and privileges which are due to them; however, he does not teach her to cope with frustration, which is related to a lack of self-control and difficulty in achieving goals, especially long-term ones. This, in turn, supports in daughters the convictions of the lack of competence and also teaches that negative scenarios are satisfied, which intensifies the sche- ma Pessimism. Such convictions of daughters may definitely negatively influence their relationships in adult life, which is worth investigating in future research.

The schema Self-sacrifice of fathers (focusing on satisfying the other's needs often at the expense of one's own needs so as not to cause pain to others) intensifies in daughters mainly pessimism and being worried, the conviction that everything that is going to happen will be difficult and also the fear of what may happen (Pessimism and Vulnerability to harm). Daughters of such fathers are also convinced that they are inferior, different, hardly effective, incapable, detached and outsiders.

In turn, the stronger developed schema of Approval seeking and Unrelenting standards in fathers (striving for and gaining approval and respect and, at the same time, setting high requirements of themselves and others) to a lesser degree creates convictions related to the necessity for daughters to suppress emotions so as to avoid the disapproval of others.

So, fathers with developed schemas which show them as weak, immature, and insecure in their convictions intensify the schemas connected with the insecurity and inferiority of daughters. Fathers perceived as strong prevent the formation of convictions about negating themselves for others.

The father/son dyad definitely has less dependencies which are significant than in the case of other dyads.

The fathers' schema Emotional deprivation (the conviction that his needs will not be satisfied or will be satisfied in the wrong way) strengthens in sons the same convictions, and, moreover, develops a sense of being different, odd, inferior and, related to this, being worried and focusing on the negative aspects of reality). Similar dependencies can be observed in the case of the schema Vulnerability to hurt, which additionally strengthens the development of convictions of one's own incompetence and setting high requirements for oneself to avoid criticism.

The father's Approval-seeking schema (striving for and gaining acceptance and respect by adjusting to the expectations of others) intensifies the sons' convictions of their own inferiority, ineffectiveness and being unable to cope. They are also more convinced that they do not match other social groups. So the Enmeshment schema is developed as well, expressing itself with the conviction that only exceptional emotional intimacy allows for experiencing positive feelings related to the "self".

On the other hand, the Emotional inhibition of fathers, expressed by avoiding emotions and spontaneous behaviour for fear of being rejected in some way, protects against the development by sons of the convictions of their own ineffectiveness; they also do not create convictions about striving for acceptance 
and making their self-assessment dependent on the assessment of others. Also, they do not make themselves submit to others at the cost of their own needs.

To sum up, as in the case of mothers, daughters react more strongly to fathers' schemas and it is, in most cases, a complementary reaction which means the creation by daughters of the beliefs resulting from their fathers' beliefs. Different fathers' schemas are more important for sons than for daughters. However, it is worth emphasizing that as in the case of mothers, the sons' beliefs were in contrast to a vision of life presented by them, whereas in the case of fathers, the sons' beliefs are more complementary.

With reference to parental attitudes, it should be noted that they have definitely weaker connections with the schemas of children. Only in the case of daughters can one see clear dependencies in the assessment of mothers' attitudes, especially in the Unrelenting standards and Incompetency schemas, which are favourable to the intensification of schemas from the domain Disconnection and rejection and Impaired autonomy. These results are consistent with the interdependence of the schemas of mothers and daughters. However, basically, there is no correlation between the attitudes of fathers and daughters or between the attitudes of both parents and the schemas of sons. This may signify that parental attitudes should be understood more as, on one hand, a way of manifesting the parents' own schemas, and on the other hand, the parental attitudes are closer to conscious control. As long as the schema is treated ego-syntonically, the way of functioning of the "self", parental attitudes are often the result of a conscious communication with others and they are also subject to control and self-monitoring.

The results presented are partially confirmed in the literature. Kadzikowska-Wrzosek (2011) in her research confirmed that parental attitudes influence boys in a different way than girls, among others in autonomy and self-regulation of emotions. Knopp (2007) in his research on the development of emotional intelligence also noted that different parental attitudes are essential for boys and girls, but in a different way. He explained this, among other things, with social expectations in which girls are more expected to enter into relationships (maybe that is why the schemas of daughters are complementary in this research), whereas boys are rather expected to have achievements (that is why there are correlations between the schemas of parents and sons, especially inverse correlations of almost all the schemas of fathers with the schema Seeking admiration/ recognition of sons). Moreover, according to Plopa (1993, 1995), mothers affect daughters' emotional sensitivity to a greater extent. Chromy (2015) noted that positive memories from childhood and positive relationships with the mother strengthen the process of identification with her and taking over her atti- tudes as a model in relationships with her own child; a negative image of a mother leads either to copying her attitudes or to counter-identification.

Grzegorzewska (2012) observed that parental attitudes during the process of their development as well as during the education of children over a period of years is characterised by a large range of changeability and stability at the same time. Changeability is connected mostly with the child's development and the change of conditions of surroundings, whereas stability results from emotional experiences, values and convictions concerning both oneself and a child in a family. If it is assumed that these convictions have their origins in the family background (Chromy, 2015), it may also signify that the shaping of these attitudes is influenced by schemas created in a family and including a broad spectrum of reality (Young et al., 2014).

Monirpoor et al. (2012) found in their research on father-child relationships that paternal care, positive emotions and a real, effective relationship with a child are correlated negatively with all schemas of children, whereas excessive support and care are favourable to higher intensification of schemas. At the same time, they stated that fathers influence the development of psychopathology in a child by their own psychopathology and by parental attitudes. These arguments support the results obtained in the present research in which the higher intensification of dysfunctional schemas of a father (thus specific psychopathology) strengthens the schemas of daughters and also - although to a lesser degree sons (Esmali Kooraneh \& Amirsardari, 2015). In their research they also confirmed that parental styles can be predictors of schemas in children - an autonomous style is related negatively to schemas from the domain Disconnection and rejection, where as an authoritarian style strengthens schemas from the domains Other directedness and Disconnection and rejection. Similar results were obtained in this study, which is clearly visible in the case of the correlation of the parental attitudes of mothers and the schemas of daughters.

In the available literature, both Polish and foreign, there is no research focusing directly on the relationships between the schemas of parents and those of their children. However, it seems that the content analysis of mutual relationships is in accordance with Young's theory. Undoubtedly, it is important to extend this subject matter by adding information concerning the strategy of dealing with a schema (excessive compensation, avoidance, giving up) (Young et al., 2014) that could partially explain the directions of dependencies whose interpretation in this study may only be a hypothesis. Moreover, an explanation of the dependencies in the domain of parental attitudes generally consistent with the current state of knowledge and Young's theory seems to entitle one to a certain extent to understand parental attitudes 
and their genesis for interpretation of their correlations in schemas.

A limitation of the present research, besides the correlation procedure which was used, was the small size of the research group. Moreover, only two-parent families with two children, a son and a daughter, were tested; the results obtained cannot be generalized to relationships in a family with one or more than two children or to situations in which a parent is bringing up a child alone.

\section{CONCLUSIONS}

On the basis of the above conclusions, a trans-generational "inheritance" of schemas can be assumed. However, it does not seem that it is a relationship which consists of children repeating their parents' schemas. Rather, children's schemas become the answer to parents' schemas - in the case of daughters, more complementary; in the case of sons, the reverse. Clear relationships, although requiring some further definition, between parental attitudes and children's schemas were observed. The present research is an initial exploration; trials were carried out on a non-clinical sample. Certainly, it would be interesting to do further research on a clinical sample, especially in the case of a parent's psychopathology. The present results may be a starting point for further verification of the problem raised.

The authors wish to thank Ms. Natalia JaniszewskaMierzyńska for the significant help in editing the text of English version of this article.

\section{REFERENCES}

Beck, A. T., Freeman, A., \& Davis, D. D. (2005). Terapia poznawcza zaburzeń osobowości [Cognitive Therapy of Personality Disorders]. Kraków: Wydawnictwo Uniwersytetu Jagiellońskiego.

Bosmans, G., Braet, C., \& Van Vlierberghe, L. (2010). Attachment and symptoms of psychopathology: early maladaptive schemas as a cognitive link? Clinical Psychology \& Psychotherapy, 17, 374-385.

Calvete, E., Orue, I., \& González-Diez, Z. (2013). An examination of the structure and stability of early maladaptive schemas by means of the Young Schema Questionnaire-3. European Journal of Psychological Assessment, 29, 283-290.

Carr, S. N., \& Francis, A. J. P. (2010). Early maladaptive schemas and personality disorder symptoms: An examination in a non-clinical sample. Psychology \& Psychotherapy: Theory, Research \& Practice, 83, 333-349.

Cecero, J. J., Marmon, T. S., Beitel, M., Hutz, A., \& Jones, C. (2004). Images of mother, self, and God as predictors of dysphoria in non-clinical sam- ples. Personality and Individual Differences, 36, 1669-1680.

Chromy, B. (2015). Międzypokoleniowa transmisja postaw macierzyńskich. Praca magisterska [Trans-generational transmission of maternity attitudes]. Retrived from https://www.repozytorium.ka.edu.pl/handle/11315/903 (12.02.2016).

Dale, R., Power, K., Kane, S., Stewart, A. M., \& Murray, L. (2010). The role of parental bonding and early maladaptive schemas in the risk of suicidal behavior repetition. Archives of Suicide Research, 14, 311-328.

Esmali Kooraneh, A., \& Amirsardari, L. (2015). Predicting early maladaptive schemas using Baumrind's parenting styles. Iranian Journal of Psychiatry and Behavioral Sciences, 9, 952.

Field, A. M., Francis, A. J. P., \& Carr, S. N. (2015). Borderline personality and depressive symptomatology: Common psychosocial predictors and comorbidity. Australian Journal of Psychology, 67, 197-206.

Grzegorzewska, I. (2012). Czy zachowania rodziców wobec dzieci są niezmienne? Uwarunkowania stabilności i zmienności sprawowania funkcji rodzicielskich [Are parents' attitudes towards children unchangeable? Conditioning of stability and changeability in being a parent]. Edukacja Dorostych, 66, 89-98.

Hoffart Lunding, S., \& Hoffart, A. (2014). Perceived parental bonding, early maladaptive schemas and outcome in schema therapy of cluster c personality problems. Clinical Psychology \& Psychotherapy. http://doi.org/10.1002/cpp.1938

Kadzikowska-Wrzosek, R. (2011). Postawy rodzicielskie a zdolności w zakresie samoregulacji: wychowawcze uwarunkowania gratyfikacji podstawowych potrzeb, internalizacji standardów oraz siły woli [Parenting and the self-regulation abilities: Educational antecedents of the satisfaction degree of basic needs, standards internalization and strength of volition]. Psychologia Rozwojowa, 16, 89-108.

Knopp, K. (2007). Inteligencja emocjonalna a temperament studentów oraz postawy rodzicielskie ich matek i ojców [Temperamental and Familial Factors in Emotional Intelligence]. Roczniki Psychologiczne, 10, 113-133.

Kriston, L., Schäfer, J., Jacob, G. A., Härter, M., \& Hölzel, L. P. (2013). Reliability and validity of the German Version of the Young Schema Questionnaire-Short Form 3 (YSQ-S3). European Journal of Psychological Assessment, 29, 205-212.

Lachenal-Chevallet, K., Mauchand, P., Cottraux, J., Bouvard, M., \& Martin, R. (2006). Factor analysis of the schema questionnaire-short form in a nonclinical sample. Journal of Cognitive Psychotherapy, 20, 311-318. 
Marchwicki, P. (2004). Style przywiązania a postawy rodzicielskie - doniesienie z badań [Attachment Styles and Parental Attitudes: an Empirical Research]. Roczniki Psychologiczne, 7, 81-103.

Mącik, D., \& Sas, E. (2015). Therapy of anorexia and Young's early maladaptive schemas. Longitudinal study. Current Issues in Personality Psychology, 3, 203-213.

Mącik, D., \& Shchehelska, K. (2015). Związki wczesnych nieadaptacyjnych schematów Younga z samopoczuciem i sensem życia w zaburzeniu lękowym i depresyjnym [Interrelations between early maladaptive schemas, well-being and sense of life in generalized anxiety and depression disorders]. Postępy Psychiatrii i Neurologii, 24, 208-216.

Monirpoor, N., Gholamyzarch, M., Tamaddonfard, M., Khoosfi, H., \& Ganjali, A. R. (2012). Role of father-child relational quality in early maladaptive schemas. International Journal of High Risk Behaviors \& Addiction, 1, 50-54.

Ostafińska-Molik, B., \& Wysocka, E. (2014). Style wychowania w rodzinie pochodzenia w percepcji młodzieży gimnazjalnej i ich znaczenie rozwojowe - próba teoretycznej i empirycznej egzemplifikacji [Parenting styles in the family of origin in the perception of junior high school students and the importance of development - attempt of the theoretical and empirical exemplification]. Przeglad Pedagogiczny, 2, 213-234.

Plopa, M. (1983). Funkcjonowanie społeczno-emocjonalne młodzieży a percepcja postaw matek i ojców [Social-emotional functioning of adolescents and perception of parental attitudes]. Psychologia Wychowawcza, 26, 129-141.

Plopa, M. (1995). Rola ojca w kształtowaniu osobowości córek i synów [The role of the father in the formation of personality daughters and sons]. In J. Trempała (ed.), Rozwijający się człowiek w zmieniającym się świecie. Materiały z IV Ogólnopolskiej Konferencji Psychologów Rozwojowych [Developing man in a changing world. Proceedings of the IV National Conference of Developmental Psychologists] (pp. 329-338). Bydgoszcz: Wydawnictwo WSP.

Plopa, M. (2008). Kwestionariusz Retrospektywnej Oceny Postaw Rodziców (KPR-ROC). Więzi w małżeństwie i rodzinie [Questionnaire of retrospective appraisal of parents' attitudes (KPRROC). Bonds in marriage and family] (pp. 161219). Kraków: Oficyna Wydawnicza "Impuls".

Saritaş, D., \& Gençö,T.(2011). Psychometric Properties of "Young Schema Questionnaire-Short Form 3" in a Turkish Adolescent Sample. Journal of Cognitive \& Behavioral Psychotherapies, 11, 83-96.

Sobański, J. A., Klasa, K., Rutkowski, K., Dembińska, E., Müldner-Nieckowski, Ł., \& Cyranka, K. (2013). Zapamiętane postawy rodziców pacjenta a obraz zaburzeń nerwicowych. Objawy związane i niezwiązane z seksualnością [Parental attitudes recollected by patients and neurotic disorders picture - sexuality-related and sexuality-unrelated symptoms]. Psychiatria Polska, 47, 827-851.

Thoma, N., Pilecki, B., \& McKay, D. (2015). Contemporary cognitive behavior therapy: A review of theory, history, and evidence. Psychodynamic Psychiatry, 43, 423-462.

Turner, H. M., Rose, K. S., \& Cooper, M. J. (2005). Parental bonding and eating disorder symptoms in adolescents: The meditating role of core beliefs. Eating Behaviors, 6, 113-118.

Young, J. E. (1999). Cognitive therapy for personality disorders: A schema-focused approach ( $3^{\text {rd }}$ ed.). Sarasota, FL, US: Professional Resource Press/ Professional Resource Exchange.

Young, J. E., Klosko, J. S., \& Weishaar, M. E. (2014). Schema therapy: A practitioner's guide. Sopot: GWP.

Young, J. E., Rygh, J. L., Weinberger, A. D., \& Beck, A. T. (2008). Cognitive therapy for depression. In D. H. Barlow (ed.), Clinical handbook of psychological disorders: A step-by-step treatment manual (4 $4^{\text {th }}$ ed., pp. 250-305). New York, NY, US: Guilford Press. 